\title{
O „MAŁYM POLACZKU” STEFANA ŻEROMSKIEGO I „PRAWDZIWEJ POLSCE” KAROLA IRZYKOWSKIEGO - PRYWATNY WYMIAR POLSKOŚCI W OBLICZU WIELKIEJ WOJNY
}

JOANNA NIEWIAROWSKA Wydział Nauk Humanistycznych Uniwersytetu Kardynała Stefana Wyszyńskiego; Faculty of Humanities Cardinal Stefan Wyszyński University jniewiarowska@wp.pl

Genezą Basi i O Adamie Żeromskim wspomnienia jest doświadczenie utraty dziecka - Basia Irzykowska umiera na chorobę nerek po trudnym dziesięciomiesięcznym leczeniu w kwietniu 1916 roku, Adam umiera na gruźlicę po kilkuletniej chorobie w lipcu 1918 roku. Obydwa utwory łączy częściowo czas opisywanych zdarzeń i czas powstania ${ }^{1}$. Można je zakwalifikować do pisarstwa autobiograficznego i warto je traktować zgodnie z rozpoznaniami Philippe'a Lejeune'a:

Autobiografie nie są przedmiotami estetycznej konsumpcji, lecz społecznymi środkami międzyludzkiego porozumienia. To porozumienie ma kilka wymiarów: etyczny, uczuciowy, referencjalny. Autobiografia została stworzona po to, aby przekazać uniwersum wartości, wrażliwość na świat,

${ }^{1}$ Trzy zeszyty dziennika Karola Irzykowskiego, ujęte prawdopodobnie przez Zofię Irzykowską tytułem „Część IV <Basia> i sprawy rodzinne” powstawały od 9 kwietnia 1916 do 14 października 1922 r., zasadnicza jednak część zapisków pochodzi z lat 1916-1918 (B. Górska, Nota wydawnicza, [w:] K. Irzykowski, Dziennik. Tom 2: 1916-1944, Kraków 2001, s. 627, w serii: K. Irzykowski, Pisma, red. A. Lam). Wspomnienie o Adamie Żeromskim powstawało w Zakopanem w kwietniu i maju 1919 r. i chronologicznie obejmuje czas życia syna od kiedy skończył dwa lata oraz kilka dni po jego śmierci, które związane były z jego pochówkiem, a więc od 1901 do 1 sierpnia 1918 r. (Z.J. Adamczyk, Uwagi wydawcy, [w:] S. Żeromski, Pisma raperswilskie. Wspomnienia i sylwetki, oprac. Z.J. Adamczyk, Warszawa 2015, s. 466-467, w serii: Pisma zebrane. Tom 24, red. Z. Goliński. Seria czwarta. Pisma spoleczne $i$ wspomnienia). 
nieznane doświadczenia - i to w ramach relacji osobistych, dostrzeganych jako autentyczne i niefikcjonalne ${ }^{2}$.

Taka perspektywa otwiera furtki interpretacyjne, które są niezwykle ważne dla poruszanego przeze mnie wątku - pozornie marginalnego w narracji o utracie, która może być bardzo zindywidualizowana $\mathrm{w}$ formie ${ }^{3}$ - polskości. Nieporównywanie skal emocjonalnych skutków utraty dziecka będzie przedmiotem mojego zainteresowania, a pewien wspólny ich element. Nieodłączne w procesie żałoby, a więc i stanowiące część opowieści o utracie jest poszukiwanie sensu śmierci bliskiej osoby. W analizowanych przeze mnie tekstach odbywa się to nie tyle w ramach indywidualnej drogi do pocieszenia (jak dzieje się np. w epicediach), ile w formie usytuowania w szerszej strukturze - narracja o utracie wtapiana jest niejako w narrację wspólnoty w kluczowym dla niej momencie historycznym i przybiera postać, którą za Reinhartem Kosselleckiem można nazwać internarracją ${ }^{4}$ Marc Augé w Formach zapomnienia pisał o tym, że człowiek żyje jednocześnie w wielu opowieściach, a oprawą pozwalającą na ich przeplatanie się (,„pochwycenie przez opowieść innego”) mogą być np. emocje i relacje afektywne. Przy czym emocje warto traktować na wzór kognitywistów i, częściowo, konstruktywistów w kategoriach zdolności uniwersalnej, mogącej jednak różnić się co do sposobów, za pomocą których emocje są wywoływane, odczuwane i wyrażane i, co szczególnie ważne, zależą zarówno od norm kulturowych, jak i od skłonności indywidualnych, jak pisze Barbara Rosenwein ${ }^{5}$. Doświadczenie utraty, łączące opowieści Żeromskiego i Irzykowskiego, wiąże się z przeżywaniem

${ }^{2} \mathrm{Ph}$. Lejeune, Wariacje na temat pewnego paktu. O autobiografii, thum. W. Grajewski i in., Kraków 2001, s. 18.

${ }^{3}$ Zob. M. Okupnik, Fenomen pamięci. O trudności badań narracji autobiograficznych o utracie, „Acta Universitatis Lodzensis. Folia Sociologica” 2012, t. 41.

${ }^{4}$ M. Augé, Życie jako opowieść, [w:] idem, Formy zapomnienia, thum. A. Turczyn, wstęp J. Mikułowski Pomorski, Kraków 2009, s. 45-46.

${ }^{5}$ B.H. Rosenwein, Obawy o emocje $w$ historii, thum. J. Wysmułek, „Teksty Drugie" 2015, nr 1, s. 380. 
silnych emocji oraz procesem żałoby i w różnym stopniu dyktuje potrzebę opowiadania będącego „owocem pamięci i zapomnienia, pracy kompozycji i dekompozycji, która tłumaczy nacisk wywierany przez oczekiwanie przyszłości na interpretację przeszłości”6. Tym, co łączy dwa zestawione przeze mnie teksty jest nie tylko ich geneza egzystencjalna, lecz także i jej kontekst, zarówno społeczno-kulturowy, jak i historyczny, w obydwu „historia jednostki zostaje rozkołysana (może nawet przechylić się w stronę śmierci), ponieważ wciąga ją wielka historia, wskutek na przykład wypowiedzenia wojny" - czytamy dalej w Formach zapomnienia. Doświadczenie utraty bliskiej osoby ma wiele wspólnego z wojną. Zygmunt Freud w 1915 roku pisał, że wiąże się przede wszystkim z przyjęciem i zmianą postawy wobec śmierci ${ }^{7}$.

Sytuacją, która określa horyzont doświadczenia opowiadających i przeżywających żałobę podmiotów (wspominający Żeromski i prowadzący dziennik choroby, śmierci i praktykowania pamięci Irzykowski) oraz przedmioty ich opowieści w świecie zdarzeń (Adam i Basia oraz ich otoczenie) jest polskość. Tę trudno definiowalną polskość na potrzeby niniejszego artykułu ujmuję w formułę zaproponowaną przez Mieczysława Porębskiego właśnie jako sytuację, którą „warunkuje [...] istnienie po części zwartej, po części żyjącej w diasporze wspólnoty duchowej, która skupia się wokół pewnych historycznie uwarunkowanych symboli, z symbolami tymi identyfikuje swe trwanie, trwania tego ciągłość i godność"». Jednocześnie wspólnota ta jest „usytuowana w świecie, w którym rządzą prawa natury, prawa i przypadki historii, w obrębie czy na skrzyżowaniu sytuacji, które uformowały się

${ }^{6}$ M. Augé, op. cit., s. 45.

${ }^{7}$ Z. Freud, Aktualne uwagi o wojnie i śmierci, tłum. A. Ochocki, M. Poręba, R. Reszke, [w:] Języki przemocy, wybór, wstęp i oprac. Ł. Musiał, Poznań 2014, s. 96.

${ }^{8}$ M. Porębski, Polskość jako sytuacja, „Znak” 2012, nr 690; http://www.miesiecznik.znak.com.pl/6902012mieczyslaw-porebskipolskosc-jako-sytuacja/ [data dostępu: 11.11.2015]. 
wcześniej, które ją współtworzyły, wchodziły z nią w wielorakie związki i parantele"9. W takim ujęciu polskość jest czymś innym niż konstrukt o fantazmatyczno-ideologicznej naturze (zbiorowe Ja idealne narodu) ukształtowany $\mathrm{w}$ warunkach nieistnienia państwa polskiego i determinowany jego brakiem $^{10}$, a czymś związanym z sytuacją każdorazowej identyfikacji symbolicznej, efektem której jest powstanie narodowej tożsamości i wpisanie się podmiotu w porządek polityczny, a celem jest/może być urzeczywistnienie narodowego projektu ${ }^{11}$.

Według Marca Augé’a, specyfiką życia ujmowanego w opowieść jest to, że skala mikro i makro (we wspólnym obszarze polskości jako bycia w i wobec pewnego symbolicznego uniwersum) nachodzą na siebie i jednocześnie mieszczą „w sobie nas samych, ponieważ tworzą naszą wersję wydarzeń i my sami mamy w nim swoje miejsce, jakkolwiek marginalne i nieistotne by ono nie było, podobnie jak tysiące czy miliony innych jednostek posiadają swoje miejsce w swojej wersji, którą same wypracowują" ${ }^{2}$. Traktuję więc

\section{${ }^{9}$ Ibidem.}

${ }^{10} \mathrm{~J}$. Sowa, Fantomowe ciato króla. Peryferyjne zmagania $z$ nowoczesna forma, Kraków 2011, s. 478. Zob. też R. Kolarzowa, „Zamawianie” Realnego. Konstruowanie tożsamości fantazmatycznej „narodu politycznego”, „Teksty Drugie" 2015, nr 1, s. 84-95. Niewątpliwie interpretacja psychoanalityczna jest w tym wypadku niezwykle kuszącą perspektywą, pozostaje ona jednak poza zasięgiem moich działań. Wydaje się jednak, że m.in. za sprawą Jana Sowy, a wcześniej Marii Janion, terminologia Lacanowska na trwałe weszła do polskiej humanistyki w obszarze badania tożsamości narodowej.

${ }^{11}$ Z. Bauman, Konstruowanie narodowej nieśmiertelności, [w:] idem, Śmierć i nieśmiertelność. O wielości strategii życia, tłum. N. Leśniewski, Warszawa 1998, s. 132-133.

${ }^{12}$ M. Augé, op. cit., s. 46. Za dopełnienie tej myśli można uznać następujące słowa: „Na każdym poziomie opowiadania autor-bohater jest bowiem zakładany jednocześnie w sposób jednostkowy i zbiorowo: po pierwsze indywidualnie, gdyż wielość opowiadań, w które jest zaangażowany, ma wpływ na każde z nich [...], co więcej, opowiadanie jego życia nie powstaje przez nałożenie się wszystkich opowiadań, ale je wszystkie przecina źródłowym znamieniem, idiosynkratycznie. Jest przy tym implikowane zbiorowo - choćby nie wiem jak bardzo była samotna przez cały bieg 
zestawione ze sobą teksty przede wszystkim jako rodzaj bardzo intymnego świadectwa przepracowywania form polskości w sytuacji Wielkiej Wojny. Podążając za rozpoznaniami Lejeune'a, można uznać, że cechuje się ono większym autentyzmem, ponieważ naznaczone jest emocjami wynikającymi z doświadczenia osobistej (z wojną bezpośrednio nie połączonej) tragedii, z którą są genetycznie i formalnie (z racji autobiograficznej formy) związane. Jednocześnie doświadczenia te są w horyzoncie wojennym sytuowane jako zdarzenia zależne od innych i interpretacyjnie determinowane emocjami wywołanymi przez wydarzenia wojenne. Stopień nasycenia problematyką polskości jest inny u Żeromskiego i Irzykowskiego - ważna dla sposobu myślenia o jej formie wydaje się sama jej obecność w narracjach o utracie.

Specyfika pisarstwa autobiograficznego (opisywana m.in. przez Lejeune'a ${ }^{13}$, a u nas przez Czermińską ${ }^{14}$, by wymienić najbardziej kanoniczne pozycje) pozwala wywodzić z zapisów autobiograficznych różne genealogie tożsamości podmiotu tego rodzaju narracji. Magdalena Saganiak w niezwykle ciekawym tekście o dziennikach Żeromskiego z lat 18821891 pokazała, jak doświadczenia autora Popiołów przełożyły się na jego

swojego życia, jednostce towarzyszy obecność innego, jako żal lub nostalgia, w taki sposób, że w różnych formach, choć zawsze wyraźna, obecność innego lub innych jest równie oczywista na poziomie opowiadania wielokrotnego lub zbiorowego. Być może jest to rodzaj gry między tymi dwoma obecnościami, które manifestują się we wszystkich typach opowieści (wyznanie, zwierzenie, pogawędki przy drinku, branie kogoś na świadka), przez co jednostka odczuwa teraz - lub będzie odczuwała potem - potrzebę rekapitulacji swojej egzystencji, opowiadania swojego życia, nadania mu spójności: byłaby to gra między «distentio» a «intentio» ducha dzielonego między pamięć, uwagę i oczekiwanie (by przywołać Augustiańskie pojęcia omówione przez Ricoeura) lub prościej, między niezgodnościa ich osobnych czasów pojedynczych i zgodnościa wielogłosowego opowiadania." (Ibidem, s. 48-49.)

${ }^{13} \mathrm{Ph}$. Lejeune, Wariacje na temat pewnego paktu. O autobiografii, op. cit.; idem, „Drogi zeszycie...”, „,Drogi ekranie...” O dziennikach osobistych, thum. M. i P. Rodakowie, wyb., wstęp i oprac. P. Rodak, Warszawa 2010.

${ }^{14}$ M. Czermińska, Autobiograficzny trójkąt: świadectwo, wyznanie i wyzwanie, Kraków 2000. 
projekt polskości i ideę miłości Ojczyzny, która stała się matrycą scalającą różne doświadczenia, nakreślającą jego horyzont etyczny i metafizyczny ${ }^{15}$. Następnie scharakteryzowała Żeromskiego jako pisarza świadomie modelującego losy swoich bohaterów w odniesieniu do tak rozumianej narodowej tożsamości - za najwyrazistszy przykład zastosowania takiej strategii pisarskiej można uznać Urodę życia, co naświetla doskonale interpretacja Anny Zdanowicz ${ }^{16}$. Krzysztof Stępnik opisał postawę Żeromskiego jako „ojca narodu” oraz - już po wojnie - działacza społecznego i politycznego, autora m.in. Snobizmu i postępu. Mateusz Chmurski wywodził z wczesnych dzienników Irzykowskiego genealogię jego tożsamości pisarskiej i krytycznej ${ }^{17}$. Inaczej ukształtowane proporcje między poszczególnymi wymiarami autobiograficznego paktu (nastawienie etyczne, uczuciowe, referencjalne) u każdego z pisarzy łączą się z innym rodzajem dojścia każdego z nich do interesującego mnie tematu: polskości.

\section{I. „Złote dni pierwszych wolności drgnień, marzeń o Polsce wolnej”18}

Jednym z najczęstszych określeń Adama Żeromskiego, charakteryzującym chłopca od najmłodszych lat, kiedy ten już „wiedział”, że trzeba się cicho zachowywać, gdy wujkowie Józef „Ziuk” Piłsudski i Stanisław „Edmund” Wojciechowski nocowali na Żabiej $4{ }^{19}$ z nakładem „Robotnika” do rozkol-

${ }^{15}$ M. Saganiak, Świat Żeromskiego czyli Polska. Początek drogi - Polska w ,Dziennikach” (1882-1891), [w:] Światy Stefana Żeromskiego. Studia, red. M.J. Olszewska, G.P. Bąbiak, Warszawa 2005, s. 319-336.

${ }^{16}$ A. Zdanowicz, Żródta i formy polskości. Uroda życia Stefana Żeromskiego, [w:] Czytanie modernizmu, red. M.J. Olszewska, G.P. Bąbiak, Warszawa 2004, s. 276-291.

${ }^{17}$ M. Chmurski, Genealogia tożsamości. „Dziennik” Karola Irzykowskiego (1891-1897), „Przegląd Humanistyczny” 2013, nr 1, s. 123-131.

${ }^{18}$ S. Żeromski, O Adamie Żeromskim wspomnienie, op. cit., s. 359.

${ }^{19}$ Żeromski i jego rodzina zajmowali służbowe mieszkanie przy ul. Żabiej $4 \mathrm{w}$ latach 1897-1903, gdy pisarz pracował jako pomocnik bibliotekarza w Bibliotece Ordynacji Zamoyskich. 
portowania w walizce, był charakterystyczny ,mały Polaczek”. Chłopiec jest więc od początku opowieści zidentyfikowany przez narratora przede wszystkim jako Polak. Zdrobnienie pojawia się w dwóch kontekstach. W pierwszym, zarysowanym powyżej, synka nieustannie sytuuje się w obrębie działalności politycznej pisarza, czyni się go „zaangażowanym”, kilkakrotnie podkreśla się bowiem jego aktywność:

Pewnego razu mały Polaczek wystąpił, zresztą z otwartością, czynnie wobec przedstawicielstwa władzy moskiewskiej. Wszystkich Moskali, żandarmów, sołdatów i w ogóle brutalów, napastników, zbójów, wszelkie widma, zmory, strachy, obrzydliwe figury, a nawet pojęcia nazywał swym własnym słowem - „Muńka"20.

W drugim przypadku określenie to staje się znaczące w kontekście fascynacji chłopca historią i kulturą francuską, a więc wtedy, kiedy bycie Polakiem wymaga usytuowania się w świecie, ukonstytuowania własnej tożsamości w szerszym układzie odniesień, z historycznie i politycznie określonego, jak to ostatnio nazwał Jan Sowa, ,punktu pikowania polskości”21. Wybór Francji na mapie tych odniesień ma charakter polityczny i odsyła do sympatii Żeromskiego ${ }^{22}$, jednocześnie wiąże się z koniecznością zachowania narodowej tożsamości i suwerenności chłopca funkcjonującego we francuskim systemie edukacji. Adam zostaje przez narratora opisany jako zorientowany politycznie uczestnik ideowo-politycznego życia ojca, by jako młodzieniec stać się ,jedynym politycznym przyjacielem”23 samego Żeromskiego. Jak trafnie zauważyła Jadwiga Zacharska,

${ }^{20}$ S. Żeromski, O Adamie Żeromskim wspomnienie, [w:] idem, Pisma raperswilskie. Wspomnienia i sylwetki, op. cit., s. 356.

${ }^{21}$ J. Sowa, op. cit., s. 373-374.

${ }^{22}$ K. Stępnik, Wojenna szarada. Twórczość Żeromskiego w latach 1914-1918, [w:] idem, Rekonesans. Studia z literatury i publicystyki okresu I wojny światowej, Lublin 1997, s. 107-137.

${ }^{23}$ W liście do syna z 8 września 1913 roku Żeromski, składając potomkowi życzenia 
we wspomnieniach dominuje przedstawianie dziecka w perspektywie historii i wobec idei, a nie w kręgu rodziny i prywatności. Pisze je ojciec, a jednocześnie ideolog, wychowawca, duchowy przywódca pokolenia. I w jego oczach widać, że nie zawsze patrzy na syna. Rola pisarza kształtuje sposób widzenia ojca, ogranicza prywatność nawet w takiej wypowiedzi, gdzie wydaje się ona zamierzona ${ }^{24}$.

Wynika to, jak wskazała badaczka, ,z dwóch sprzecznych dyrektyw kształtujących tekst i określających jego funkcje, a mianowicie użytkowej i poetyckiej (literackiej), dokumentacyjnej i idealizacyjnej" ${ }^{25}$, gdzie porządek faktów podlega jednak porządkowi parenezy, ,prezentującemu wzorzec małego Polaka i ideał młodzieńca od najwcześniejszego wieku przygotowywanego do roli zbawcy Ojczyzny"26, co ma decydujący wpływ na kompozycję Wspomnienia ..., jego narrację i prawdopodobieństwo psychologiczne w kreacji Adama. Momentami jednak perspektywa wyraźnie zorientowanego politycznie działacza, ale i pisarza-moralisty, tego, który dał żołnierzom Legionów Popioty, ustępuje emocjom, nie tyle jednak ojcowskim, co po prostu intymnym ${ }^{27}$. Zilustrować można to fragmentem opisującym świa-

urodzinowe, wyraża jednocześnie swoje oczekiwania wobec niego: „w Zakopanem rozwiniesz się na tęgiego Polaka i dzielnego człowieka" - S. Żeromski, Listy 19131918, oprac. Z.J. Adamczyk, Warszawa 2008, s. 110; Zob. B. Olech, Adam Żeromski w listach $i$ wspomnieniach Stefana Żeromskiego, [w:] Żeromski. Tradycja i eksperyment, idea i układ J. Ławski, red. A. Janicka, A. Kowalczykowa, G. Kowalski, Białystok-Rapperswil, s. 207-208.

${ }^{24}$ J. Zacharska, Między fikcją a dokumentem. ,O Adamie Żeromskim wspomnienie”, [w:] Światy Stefana Żeromskiego, op. cit., s. 106.

${ }^{25}$ Ibidem, s. 102.

${ }^{26}$ Ibidem.

${ }^{27} \mathrm{M}$. Głowiński przeprowadził interesującą analizę Wspomnienia ... w perspektywie poetyki, określając dwustylowość, wynikającą z dwóch tendencji kształtujących pisarstwo Żeromskiego (realistycznej i poetyckiej), jako jego cechę charakterystyczną i cechę charakterystyczną prozy autora Wiernej rzeki w ogóle M. Głowiński, Proza żałobna Żeromskiego, [w:] Żeromski. Tradycja i eksperyment, op. cit., s. 197-202. B. Olech zaś wskazuje na to, że relację Stefan-Adam określały trzy dopełniające się układy ról: ojciec-syn, mistrz-uczeń, parter-partner - B. Olech, Adam Żeromski w listach i wspomnieniach Stefana Żeromskiego, op. cit., s. 209-210. 
domość polityczną Żeromskiego-syna, „niepokonanego szydercy” i „ciętego krytyka” „dygnitarzy lub mniemanych dobrodziejów narodu”:

Były to istne strzały toreadora, rzucane niepostrzeżenie w kark głupiego byka, gdy się miotał po arenie, sam nie wiedząc, w którą biec stronę. Jakżem was kochał, wy chybkie strzały, ciskane subtelną ręką mego jedynego politycznego przyjaciela ${ }^{28}$.

Wynika z tego, że wspomnienie jednocześnie daje się ująć w formułę opowieści parenetycznej, jak wskazuje Zacharska, w której Adam staje się figurą i wzorem Polaka, w najwyższej mierze zdeterminowanego miłością Ojczyzny, ale jednocześnie przedstawia go jako krytycznego i niezależnego intelektualnie w obszarze politycznej praktyki. By zrozumieć ciężar tej straty, należy przyjrzeć się postawie Żeromskiego-narratora. Ten rekonstruuje biografię Adama wybiórczo, uwzględniając przede wszystkim to, co jest istotne z perspektywy polskiej tożsamości w obliczu określonej sytuacji społeczno-politycznej - tekst bowiem pisany jest wiosną 1919 roku, a więc w obliczu wyzwania budowy państwowości polskiej. Wewnętrzna budowa utworu zorganizowana jest wokół napięcia między trwałym, spójnym sposobem kreacji głównego bohatera a niejednolitą perspektywą narracyjną. Narrator bowiem oscyluje między zdystansowanym opowiadaniem, unikającym mówienia w pierwszej osobie (wbrew zapowiedzi podtytułowej ${ }^{29}$ ), a opowiadaniem pozwalającym utożsamić go z Żeromskiem-pisarzem i moralistą, autorytetem publicznym, który w czasie wojny przyjmuje jednak postawę politycznie niezadeklarowaną $a^{30}$, a także opowiadaniem posiadającym cechy narracji ojcowskiej, co paradoksalnie w tekście jest najrzadsze,

${ }^{28}$ S. Żeromski, O Adamie Żeromskim wspomnienie, op. cit., s. 431.

${ }^{29}$ Pełny tytuł wspomnienia brzmi: O Adamie Żeromskim wspomnienie przez jego ojca jako rękopis w 55 egzemplarzach podane do druku, dla grona osób, które taska miłości, przyjaźni i opieki darzyły zgastego.

${ }^{30}$ K. Stępnik, op. cit., s. 109-113. 
częstsze w jego końcowych partiach, kiedy mówi się o śmierci i pochówku dziewiętnastolatka (wyznaczając intersubiektywną przestrzeń dla wspólnego przeżywania, uruchamia tym samym możliwość empatii). Niekonsekwencje te, które zrekonstruowała dokładnie Jadwiga Zacharska, skłaniają do lektury Wspomnienia... wyczulonej na to, co przemilczane, niedopowiedziane, niekiedy wręcz sprzeczne ze zrekonstruowanymi przez badaczy szczegółami z biografii pisarza ${ }^{31}$. Skłaniają też do zadania pytania (wykraczającego poza ramy tego szkicu) o rzeczywiste funkcje Wspomnienia ..., o jego miejsce pośród takich tekstów jak Wista ${ }^{32}$, Początek świata pracy czy Projekt Akademii Literatury Polskiej, a więc o jego znaczenie w obrębie całości ideowo-programowej pisarza względem niepodległości i w kontekście roli przypisywanej sobie przez niego w obliczu bieżących zdarzeń. Gatunkowa rozległość działalności pisarskiej Żeromskiego jest w tym czasie, zdaniem Krzysztofa Stępnika, wyrazem ,wewnętrznej aktywności, żywotności wolnej myśli i emocji, które są prawdziwym warunkiem suwerenności podmiotu twórczego w jego racjach artystycznych i ideowych"33. Opowieść o synu staje się nasyconą emocjami formą poświadczenia polskości jako pewnego projektu do zrealizowania w określonej sytuacji społeczno-politycznej. Staje się wyjątkowym świadectwem potwierdzającym wagę i konieczność utrwalenia wspólnoty narodowej. Wskazuje jednocześnie na postawę, która taki projekt wspiera - krytycznego myślenia i intelektualnej suwerenności. Jednocześnie, jak się wydaje, narracja sprowokowana przez utratę staje się przestrzenią samopotwierdzenia tożsamości Żeromskiego, który, parafrazując Jacques’a

${ }^{31}$ Przykładem przyjęcia określonej strategii pisarskiej zdaje się pomijanie lub zafałszowywanie motywacji niektórych sytuacji z biografii Adama, np. tych które dotyczą relacji pisarza z Moniką Żeromską - zob. m.in. Z.J. Adamczyk, Uwagi wydawcy, op. cit., s. 465-466.

${ }^{32}$ Zob. M. Saganiak, ,,Wista” Stefana Żeromskiego - misterium przyrody i historii, [w:] Czytanie modernizmu, op. cit., s. 313-329.

${ }^{33}$ K. Stępnik, op. cit., s. 137. 
Derridę, „odpowiada na wezwanie lub przypisanie tego, co uniwersalne" 34 . Samopotwierdzenie to wymaga postawy zaangażowania intelektualnego i odpowiedzialności, wiąże się jednak też z wpisaną weń przygodnością i partykularnością oraz emocjami. Adam Żeromski umiera na gruźlicę w 1918 roku, a narrację wspomnieniową zaczyna - im bliżej tragicznego finału przenikać emocjonalny ton wypowiedzi Żeromskiego-ojca. Śmierć „małego Polaczka” została ujęta w narracji pisarza w szerszą strukturę sensu, jaką jest polska tożsamość. Ma to oczywiście wymiar terapeutyczny, nieodłącznym bowiem elementem żałoby jest usensownienie śmierci osoby bliskiej ${ }^{35}$. Można powiedzieć, że przygodność śmierci Adama domaga się we wspomnieniu Żeromskiego, dającego pociechę usytuowania, jednak realność osobistej straty nie pozwala na jej proste wpisanie w schemat przynoszący ukojenie - nieprzekonujący jest porządek ,śmiertelności skolektywizownej”, gdy rówieśnicy syna ginęli za ojczyznę w różnych formacjach wielkowojennych (niekiedy walcząc przeciw sobie) $^{36}$. W obliczu realnej konieczności budowy państwa polskiego i związanych z tym wyzwań (horyzont etyczny dla tych, którzy przeżyli) Żeromski może być szczególnie świadomy pustego miejsca, zajmowanego przez takich chłopców jak Adam - obdarzonych zmysłem politycznym i niezależnym sądem. Zarówno postawa wojenna Żeromskiego, jak i postawa Żeromskiego-narratora Wspomnienia... dowodzą tego, co zasygnalizował Krzysztof Stępnik, a w planie teoretycznym opisał Zygmunt Bauman - paradoksalnie potwierdzają godność polskości jako projektu, ale

${ }^{34}$ J. Derrida, L'Autre Cap, Editions de Minuit, Paris 1991, s. 49, 71-72, cyt. za: Z. Bauman, Konstruowanie narodowej nieśmiertelności..., s. 135.

${ }^{35}$ A.M. di Nola, Triumf śmierci. Antropologia żałoby, red. M. Woźniak, thum. J. Kornecka, Kraków 2006.

${ }^{36}$ Żeromski jednak opisuje syna jako dzielnego żołnierza w formacji skautingowej. Widzi go jednocześnie jako tego, który chciałby i powinien walczyć, gdyby nie powstrzymywała go choroba (por. J. Zacharska, op. cit., s. 106). Obok zapału młodych chłopców zaprawiających się do wojny, wspomina też Żeromski o trudnej sytuacji żołnierzy rozwiązanego Legionu Wschodniego. 
wymagają jego rewizji w planie praktycznej realizacji, konkretnych działań politycznych. Żeromski, również pod wpływem osobistej tragedii, dystansuje się wobec ruchów niepodległościowych wywiedzionych z tradycji romantycznej (kultywowanych w kręgu Legionów), a opowiada się po stronie nowoczesnego projektu, który za cel obrał sobie działanie na rzecz przyszłej niepodległej Polski. Polskość w sytuacji wojennego przełomu domaga się innej formy aniżeli ta wypracowana w odmiennych warunkach - przeszłość nie może być matrycą dla budowania przyszłości, ponieważ trwałość i transcendentność polskości określana jest przez jej realną sytuację kulturową i polityczną, a nie przez wypracowany w dziewiętnastowieczu konstrukt wyobrażeniowy. Żeromski, tak jak w przypadku fikcyjnych losów Piotra Rozłuckiego $^{37}$, personalizuje polskość, by ją potwierdzić. Pojedyncza śmierć wpisuje się w projekt nieśmiertelnej ciągłości narodowej, jednak dzieje się to pewnym kosztem (wyraźnie sygnalizowanym) - braku tych, którzy będą tę ciągłość poświadczać w konkretnych działaniach politycznych, nacechowanych niezależnością intelektualną i krytycznym myśleniem. Lęk i ból, które przyniosła śmierć syna mogą zostać skompensowane w aktywnej działalności politycznej, pozostaje jednak świadomość, że nie ma kto wziąć na siebie ciężaru budowania realnego państwa narodowego. W tym kontekście Wspomnienie... można interpretować jako dzieło oddające dynamikę potwierdzania polskości - postulatu etycznego i polskości - przestrzeni jego realizacji. Przy czym w tym drugim przypadku nie przynosi ono takiego pocieszenia, jakiego paradoksalnie wymaga sam projekt (pełnego poświęcenia i braku autonomii), bo trzeba ponieść koszty „,narodowej nieśmiertelności”38.

${ }^{37}$ Jeszcze wydatniej sytuacja ta potwierdza się w przypadku Włodzimierza Jasiołda, bohatera pisanej w latach 1914-1918 Charitas, zwłaszcza, że powieść osadzona jest w realiach Wielkiej Wojny i można ją uznać za ideowo-polityczny komentarz pisarza dotyczący wojennych postaw - zob. K. Stępnik, op. cit., s. 122-131.

${ }^{38}$ Z. Bauman, Samolubny gatunek, [w:] Śmierć i nieśmiertelność, op. cit., s. $132-133,148-149$. 
Polskość domaga się tutaj nowoczesnej formy, kształtu politycznego, który należy skonstruować, który będzie konstruował Żeromski w działalności publicystycznej w pierwszych latach niepodległości.

\section{II. „Trzy sposoby zachowywania się wobec rzeczywistości: być w niej, przypominać sobie ją i śmierć"39}

Gdy jednak spojrzę na jej fotografie, na to czoło wysokie i oczy śliczne i mądre, wierzyć nie chcę, żeby to mogło zaginąć. Dla mnie to jest istotna Polska, prawdziwa moja Polska ${ }^{40}(15 / 5 / 1916)$.

Gdy dziś pisałem biuletyny wojenne $\mathrm{z}$ tych rozstrzygających dla mnie dni lipca, tyle zabitych i jeńców, tylko mi to przychodziło na myśl, co się wtedy z Basią działo. To tło czarno-czerwone ogólnej rzezi już zbyt mi jest zwyczajne, aby na mnie wywierało wrażenie. Mikrokosmos jest tak samo wielki jak makrokosmos. A śmierć takiego małego dzieciątka jest dla mnie tragiczniejszą, a przynajmniej większym napawa mnie smutkiem, niż śmierć stu bohaterów. Oni na to są bohaterami, aby ginęli, w ogóle gdy umiera człowiek dorosły, to niejako na własny rachunek, dorasta do swego losu, może go nieść - ale tu się odczuwa niesłychaną krzywdę i niesprawiedliwość, chciałoby się objąć część tej śmierci, a nie można - to nie śmierć zresztą, ale katusza jednoroczna, więzienie z torturami i głodem, powolne podcinanie ciała i ducha [...] już mnie nie przeraża. Co mi wojna! A jeżeli jest prawdą, że B[asia] od początku wojny już była wskutek czerwonki chora na nerki, to może to pozostaje $\mathrm{w}$ związku, i teraz powinien nastać pokój. Umarła mi cała moja Polska, jedyna, którą znałem i naprawdę kochałem. Nie ma dla mnie Polski, w której Basia nie żyje ${ }^{41}$ (9/7/1916).

Wspomnienie Żeromskiego zdominowane jest przez etyczny wymiar autobiograficznego paktu, dziennik Karola Irzykowskiego przybiera zgoła inną postać. Różnica formy zapisu egzystencjalnego doświadczenia utraty dziecka

${ }^{39}$ K. Irzykowski, Dziennik. Tom 2: 1916-1944, w serii: K. Irzykowski, Pisma, red. A. Lam, Kraków 2001, s. 81. Zapis pochodzi z 17 października 1916 roku. W tekście po cytacie w nawiasie okrągłym podaję datę zapisku.

${ }^{40}$ Ibidem, s. 19.

${ }^{41}$ Ibidem, s. 46. 
wynika z odmienności spełnianej przez niego funkcji. Jak wskazuje tytułowy cytat z dziennika, jest on formą doświadczania rzeczywistości (i przekazywania prawdy tego doświadczenia) ${ }^{42}$, formą praktykowania pamięci (obok refleksji metapamięciowej stanowi medium tego, co Astrid Erll określiła jako collected memory ${ }^{43}$ ), a także miejscem refleksji natury metafizycznej: dociekania prawdy na temat śmierci - formującego faktu egzystencjalnego. Jeśli biografia Adama Żeromskiego wpisana była w symboliczne uniwersum polskości jako sytuacji domagającej się identyfikacji i potwierdzania, polskości jako wyzwania i nakazu moralnego, to Irzykowski przyjmuje odmienną postawę nie rzutuje skali makro na skalę mikro, ale odwrotnie, mikrokosmos polskości, za jaki uznaje swoją umierającą córkę, jest dla niego tak samo wielki jak makrokosmos. Basia jest ,„prawdziwą” Polską, nie Polską-ideą, a czymś rzeczywistym. Można uznać, że, podobnie jak w przypadku Gombrowicza, istotna jest tutaj opozycja rzeczywiste-nierzeczywiste ${ }^{44}$. Basia, dopóki żyje i dopóki jest pamiętana, dopóty sytuuje się po stronie rzeczywistości, konkretu, codzienności, a nawet teraźniejszości. Trudno zrozumieć to utożsamienie Basi z Polską inaczej niż w perspektywie refleksji tanatologicznej Irzykowskiego, wywołanej podstawowym doświadczeniem egzystencjalnym - utratą dziecka, ale rozpatrywanym w kontekście masowej śmierci „bohaterskiej” na frontach wojny, którą autor Pałuby obserwuje z perspektywy pracownika Biura

${ }^{42}$ Można powtórzyć za Pawłem Rodakiem, że ma w pewnym sensie wymiar performatywny (kształtuje je przez zapis) - idem, Między zapisem a literatura. Dziennik polskiego pisarza w XX wieku (Żeromski, Natkowska, Dąbrowska, Gombrowicz, Herling-Grudziński), Warszawa 2011, s. 116-117.

${ }^{43}$ Według Astrid Erll w odróżnieniu od collective memory, collected memory to społecznie i kulturowo ukształtowana pamięć indywidualna - idem, Literatura jako medium pamięci zbiorowej, thum. M. Saryusz-Wolska, [w:] Pamięć zbiorowa i kulturowa. Współczesna perspektywa niemiecka, red. M. Saryusz-Wolska, Kraków 2009, s. 212-213. Por. A. Assmann, Cztery formy pamięci, thum. K. Sidowska, [w:] idem, Między między historiq a pamięcia. Antologia, red. i posł. M. Saryusz-Wolska, Warszawa 2013, s. 41-43, 47-51.

${ }^{44}$ P. Rodak, op. cit., s. 456-457. 
Korespondencyjnego w Krakowie, a więc mającego dostęp do najnowszych informacji i doniesień. W wielu miejscach dziennika Irzykowski świadomie zderza rzeczywistość domową, naznaczoną chorobą i śmiercią, z rzeczywistością wojenną, ale interesują go przede wszystkim imponderabilia, czyli to, co pozornie najmniej potrzebne w procesie rozumienia i samorozumienia. Basia jest rzeczywista w przeciwieństwie do nierzeczywistości wojny, która jako bezosobowa siła chciałaby zawłaszczyć całe doświadczenie i podporządkować je nierzeczywistym: makrokosmosowi, kolektywowi/narodowi, historii czy przyszłości. Wojna chciałaby „pochwycić” jego opowieść i tym samym ukoić ból - wpisać utratę w opowieść o ,śmierci skolektywizowanej”, by znów odwołać się do terminologii Baumana. Wydaje się, że w tych kilku miejscach dziennika, gdzie temat polskości się pojawia, obecna jest również przestroga przed polskością, w której utożsamienie z nią pociągać musi za sobą gotowość na śmierć z góry usprawiedliwioną, śmierć w imię politycznej woli. Można powiedzieć, że Irzykowski sprzeciwia się nowoczesnej śmierci skolektywizowanej, przeżywając żałobę częściowo w paradygmacie dziewiętnastowiecznym opisanym przez Philippe'a Ariès jako hipertroficzną, związaną z kultem pamiątek, przesadną dbałością o miejsca pamięci: „śmierć dziewiętnastowieczna [...] nie jest śmiercią, której człowiek lęka się dla siebie, zdradziecko na nas czatującą, lecz śmiercią, która nam odbiera ukochanych, śmiercią drugiego człowieka"45. Irzykowski przeżywa stratę konwencjonalnie: w procesie żałoby, w sposób zrytualizowany, do czego odnoszą się opisy zamawiania maski pośmiertnej, częstych wypraw na cmentarz, dbałości o grób, planowania pomnika, i subiektywnie, wewnętrznie: w formie dziennikowego zapisu, dotyczącego nie tylko wydarzeń, lecz także emocji oraz zawierającego ogólniejszej natury refleksję metafizyczną (przede wszystkim na temat

${ }^{45} \mathrm{Ph}$. Ariès, Śmierć drugiego człowieka, tłum. M. Ochab, [w:] Wymiary śmierci, red. S. Rosiek, Gdańsk 2010, s. 171. 
pamięci i śmierci $\left.{ }^{46}\right)^{47}$. Zarówno jednej, jak i drugiej formie radzenia sobie z sytuacją towarzyszą silne emocje, pomimo tego, że świat masek, ról i rytuałów społecznych był wcześniej przedmiotem krytyki samego Irzykowskiego, ale też chwalonych przez niego pisarzy (zwłaszcza Nałkowskiej). Poprzez tworzenie pamięci zawiązuje się afektywną miniwspólnotę żałoby, pisanie dziennika zaś spełnia funkcje autoterapeutyczną i autoanalityczną ${ }^{48}$, gdyż człowieka doświadczonego utratą czyni kimś samotnym. Myśl o śmierci, której fragmenty znajdujemy w dzienniku, Irzykowski rozwija w artykule dla „Masek” z 1918 roku: ,jest też jedna linia, która prowadzi w ciemną głąb lub w jasną wyż - jak kto woli, i ta przypomina, iż pod tą maską codzienności

${ }^{46}$ Więcej na temat stosunku Irzykowskiego do śmierci pisze J. Jakóbczyk, Diarysta Karol Irzykowski, [w:] idem, Szachy literackie? Rzecz o twórczości Karola Irzykowskiego, Katowice 2005, s. 27-30.

${ }^{47}$ E. Kraskowska w znakomitym studium poświęconym Basi, by pokazać tę dwuwymiarowość doświadczenia utraty, używa narzędzi neopsychoanalizy; mówi o psychologii i rytuale żałoby, Realnym i Symbolicznym - idem, Ojcowska żałoba Karola Irzykowskiego, „Teksty Drugie” 2008, nr 5, s. 133-134. Zapis doświadczenia utraty w dzienniku Irzykowskiego można byłoby również interpretować w optyce Freudowskiego rozróżnienia na żałobę i melancholię, konwencjonalny procesu godzenia się z utratą, gdy „nic z tego, co zostało utracone, nie jest nieświadome” (Z. Freud, Żałoba $i$ melancholia, [w:] idem, Psychologia nieświadomości, tłum. R. Reszke, Warszawa 2007, s. 149), i sytuację, w której „nie potrafimy jednak jednoznacznie stwierdzić, co właściwie zostało utracone” (ibidem). Można stwierdzić, że pewne elementy opisywanego przez autora Pałuby doświadczenia zbliżają je do tego, co Freud opisał jako melancholię, jednak wymagałoby to dokładniejszego zbadania. Jeśli w tym kontekście zastanowić się nad sensem utożsamienia Basi z Polską w momentach najbardziej nasilonego bólu po utracie, to można by je uznać za potwierdzające diagnozę o stanie melancholii Irzykowskiego - śmierć Basi jest sytuowana względem innych doświadczeń, które nabierają w jego narracji charakteru paralelnego (obiektem utraty może być również ojczyzna). Chory „wprawdzie zdaje sobie sprawę, kogo stracił, nie potrafi jednak stwierdzić, co oznacza ta strata" (ibidem).

${ }^{48} \mathrm{Za}$ Pawłem Rodakiem wskazuję funkcję autoanalityczną (P. Rodak, op. cit., s. 44-48), a nie funkcję konstruowania tożsamości, bo wydaje się, że doświadczenie, które jest głównym przedmiotem dziennika - choroba i śmierć - staje się przestrzenią zarówno konstrukcji, jak i dekonstrukcji tożsamości podmiotu, co mogłaby potwierdzić jego interpretacja w kontekście Freudowskiej melancholii (zob. przypis powyżej). 
w śmierci zawiera się cudowność, zrozumiałą i wyczuwalna tylko dla ginącego osobnika lub dla jego najbliższych"49. Śmierć okazuje się tym, co najbardziej rzeczywiste, co jednocześnie cudownie nielogiczne. Przypisywanie śmierci jakiejś logiki, wpisywanie jej w inne opowieści, zwłaszcza kolektywne (,patos tresury bohaterskiej”), jest według Irzykowskiego prawdziwą przyczyną Wielkiej Wojny:

Filozofia koralowa uczy, żeby sobie nic nie robić z śmierci, ponieważ ginie tylko marna jednostka, ale gatunek, ród, ojczyzna żyje dalej, a w nich przecież i owa jednostka żyje wiecznym życiem - w stosownej przeróbce. Jesteśmy wieczni, bo jesteśmy przecież społeczeństwem korali, które narastają wciąż jedne na drugich i rozgałęziają się jak drzewa w oceanie bytu ${ }^{50}$.

Zbiorowej nieśmiertelności (bo skonstruowanej w przestrzeni mentalnej w imię zbiorowych interesów) przeciwstawia Irzykowski realność i godność, poprzez śmierć dotyka niejako Realnego - zgodnie z terminologią Lacana. Polskość Basi, inaczej niż w przypadku bohaterskich chłopców, nie jest wynikiem pracy identyfikacji, ponieważ ona nie była jeszcze świadoma istnienia takiej wspólnoty symbolicznej, jaką jest naród. Świadomy trudu identyfikacyjnego mógł być sam Irzykowski, który ją w tym porządku umieścił, nazywając prawdziwą Polską, ale jednocześnie wskazując na to, że śmierć jest obszarem, który go unieważnia, wręcz dyskryminuje. Z pewnością zdyskryminowana jest polskość, próbująca nadać sens śmierci, przesłonić jej cudowną realność i teraźniejszość.

20 października 1916 roku Irzykowski pisze, że ,jesteśmy w więzieniu, zamkniętym śmiercią, poza tym nie ma niczego”, a „Basia jest tłem, na

${ }^{49}$ K. Irzykowski, Filozofia koralowa wobec religii, „Maski” 1918, z. 22; cyt. za: K. Irzykowski, Filozofia koralowa a religia, [w:] Słoń wśród porcelany. Lżejszy kaliber, oprac. Z. Górzyna, w serii: K. Irzykowski, Pisma, red. A. Lam, Kraków 1976, S. 509.

${ }^{50}$ Ibidem, s. 509-510. 
którym się wszystko [...] rozgrywa"51 (20/10/1916). Wspomnienie o córce stało się w jego życiu swoistym memento mori, które ma dużą wagę egzystencjalną, a w polu doświadczeń wojennych jest też osobistą przestrogą przed depersonalizacją człowieka poddanego jej mechanizmom. Po śmierci Basi Irzykowski jest gotowy „wziąć udział w wojnie”, nie tylko „piórem”, jak wtedy gdy pisał o związkach wojny i estetyki w 1914 roku $^{52}$, lecz także przez bezpośrednią walkę, pozostaje jednak niezależny, świadomy trwogi i bólu, jaki wiąże się z faktem konfrontacji ze śmiercią. Jednocześnie wyraża gotowość na tę ostateczną konfrontację $e^{53}$.

Dla Irzykowskiego śmierć Basi stanowi okazję do filozoficznej refleksji na temat wojny - jej tłem są rozważania nad nowoczesną kondycją podmiotu, zwłaszcza jego postawą wobec śmierci w ogóle. Irzykowski sprzeciwia się tej postawie, nie akceptuje jej, występuje przeciwko ,śmierci skolektywizowanej”, śmierci, którą wojna pozbawiła właściwego egzystencjalnego, indywidualnego wymiaru. Sprzeciwia się zawłaszczaniu Basi przez wojenną opowieść, a więc i temu, co nazwał w 1913 roku - krytykując Urodę życia - „hienizmem narodowym”54, domagającym się świadectw grobu i krwi. Tym samym opowiada się po stronie cudownego potencjału teraźniejszości, jednostkowości i ludzkiej godności. Służy temu nie kształtowanie collective memory, a przepracowanie collected memory - kultywowanie indywidualnej pamięci o zmarłej.

${ }^{51}$ Idem, Dziennik..., s. 84.

${ }^{52}$ Idem, Czynnik sztuki w wojnie, „Nowa Reforma” 1914, nr 339, s. 256-260.

${ }^{53}$ Gotowość Irzykowskiego do wzięcia udziału w wojnie i możliwości poniesienia śmierci odczytywana może być jako objaw skłonności samobójczych związanych z melancholią (Z. Freud, Żałoba i melancholia, op. cit., s. 154).

${ }^{54}$ Idem, Ze szkoty Żeromskiego. ,, Uroda życia”, [w:] Czyn i słowo oraz Fryderyk Hebbel jako poeta konieczności, Lemiesz i szpada przed sądem publicznym, Prolegomena do charakterologii, oprac. Z. Górzyna, wstęp A. Lam, Kraków 1980, s. 595, w serii: K. Irzykowski, Pisma, red. A. Lam. 
Można powiedzieć, że wspomnienie o Adamie Żeromskim jest podporządkowane perspektywie społecznej, właśnie owej szerszej ramie collective memory, co pozwala zrozumieć, dlaczego syn jest w opowieści Żeromskiego „małym Polaczkiem”, a Basia jest przedmiotem pamięci psychicznej i indywidualnej oraz czemu może być wielką Polską. W tym sensie oba teksty stanowią media kultury pamięci, ale na różnych poziomach. Opowieść o Adamie ma na celu ustanowić i potwierdzić wzór, ukształtować postawę, ukonstytuować tożsamość, wyznaczając zadanie do wykonania, dopełnienie sytuacji polskości w obszarze materialno-praktycznym związane z postulatem etycznym. Autentyczność tego wzoru poświadcza Żeromski-narrator i Żeromski autor pism publicystycznych w latach powojennych. W dzienniku Irzykowskiego medium zapisu pozwala na pośredniczenie i transponowanie między pamięcią indywidualną o Basi a pamięcią zbiorową, jednocześnie stanowi ostrzeżenie przed zawłaszczeniem prawa do prywatnego wymiaru polskości przez wielkie narracje, dyskryminujące przygodność, teraźniejszość, życie.

Dawanie świadectwa tak trudnemu osobistemu doświadczeniu egzystencjalnemu, z jakim mierzą się Żeromski i Irzykowski - pisarze, których zarówno w wymiarze estetycznym, jak i polityczno-ideowym trudno porównywaćs ${ }^{55}$ - paradoksalnie wiąże się koniecznością ponownego usytuowania się w i wobec polskości. W sposób nieodłączny dookreśla i determinuje tę sytuację doświadczenie Wielkiej Wojny, co zdaje się potwierdzać rozpoznania badaczy o przełomowym charakterze lat 1914-1918 ${ }^{56}$. Doświadczenia:

${ }^{55}$ Chyba że za pomocą przyimka „wobec”, wszak koncepcja literatury wypracowana przez młodszego o pokolenie Irzykowskiego formowała się polemicznie między innymi względem twórczości Żeromskiego. Takiemu ujęciu poświęciła swój referat Sylwia Panek na konferencji Stefan Żeromski wobec tradycji i nowoczesności, która odbyła się w dniach 19-20 listopada 2014 r. w Muzeum Literatury im. Adama Mickiewicza w Warszawie.

${ }^{56}$ Zob. m.in. D. Kielak, Wielka Wojna i świadomość przetomu. Literatura polska lat 1914-1918, Warszawa 2001. 
utraty, wojny, polskości - wyznaczają również nowy układ współrzędnych, który dookreśli sytuację, jaką stanie się polskość dla każdego z pisarzy w niepodległym kraju.

\section{Bibliografia:}

Philippe Ariès, Śmierć drugiego człowieka, tłum. M. Ochab, [w:] Wymiary śmierci, red. S. Rosiek, Wydawnictwo słowo/obraz terytoria, Gdańsk 2010.

Aleida Assmann, Cztery formy pamięci, thum. K. Sidowska, [w:] idem, Między między historia a pamięcia. Antologia, red. i posł. M. SaryuszWolska, Wydawnictwa Uniwersytetu Warszawskiego, Warszawa 2013.

Marc Augé, Życie jako opowieść, [w:] idem, Formy zapomnienia, thum. A. Turczyn, wstęp J. Mikułowski Pomorski, Towarzystwo Autorów i Wydawców Prac Naukowych Universitas, Kraków 2009.

Zygmunt Bauman, Śmierć i nieśmiertelność. O wielości strategii życia, tłum. N. Leśniewski, Wydawnictwo Naukowe PWN, Warszawa 1998.

Mateusz Chmurski, Genealogia tożsamości. „Dziennik” Karola Irzykowskiego (1891-1897), „Przegląd Humanistyczny” 2013, nr 1, s. 123-131.

Małgorzata Czermińska, Autobiograficzny trójkąt: świadectwo, wyznanie $i$ wyzwanie, Towarzystwo Autorów i Wydawców Prac Naukowych Universitas, Kraków 2000.

Astrid Erll, Literatura jako medium pamięci zbiorowej, thum. M. SaryuszWolska, [w:] Pamięć zbiorowa i kulturowa. Wspótczesna perspektywa niemiecka, red. M. Saryusz-Wolska, Towarzystwo Autorów i Wydawców Prac Naukowych Universitas, Kraków 2009. 
Zygmunt Freud, Aktualne uwagi o wojnie $i$ śmierci, thum. A. Ochocki, M. Poręba, R. Reszke, [w:] Języki przemocy, wybór, wstęp i oprac. Ł. Musiał, Wydawnictwo Nauka i Innowacje, Poznań 2014.

Zygmunt Freud, Żaloba i melancholia, [w:] idem, Psychologia nieświadomości, tłum. R. Reszke, Wydawnictwo KR, Warszawa 2007.

Michał Głowiński, Proza żalobna Żeromskiego, [w:] Żeromski. Tradycja i eksperyment, idea i układ J. Ławski, red. A. Janicka, A. Kowalczykowa, G. Kowalski, Książnica Podlaska im. Łukasza Górnickiego w Białymstoku, Białystok-Rapperswil 2013.

Karol Irzykowski, Czynnik sztuki w wojnie, „Nowa Reforma” 1914, nr 339, [za:] Karol Irzykowski, Pisma rozproszone, t.1: 1897-1922, oprac. J. Bahr, Wydawnictwo Literackie, Kraków 1998.

Karol Irzykowski, Dziennik. Tom 2: 1916-1944, oprac. B. Górska, Wydawnictwo Literackie, Kraków 2001.

Karol Irzykowski, Filozofia koralowa a religia, [w:] Stoń wśród porcelany. Lżejszy kaliber, oprac. Z. Górzyna, Wydawnictwo Literackie, Kraków 1976.

Karol Irzykowski, Ze szkoty Żeromskiego. , Uroda życia”, [w:] Czyn isłowo oraz Fryderyk Hebbel jako poeta konieczności, Lemiesz i szpada przed sqdem publicznym, Prolegomena do charakterologii, oprac. Z. Górzyna, wstęp A. Lam, Wydawnictwo Literackie, Kraków 1980.

Jan Jakóbczyk, Diarysta Karol Irzykowski, [w:] idem, Szachy literackie? Rzecz o twórczości Karola Irzykowskiego, Wydawnictwo Uniwersytetu Śląskiego, Katowice 2005.

Dorota Kielak, Wielka Wojna i świadomość przełomu. Literatura polska lat 1914-1918, Wydawnictwo UKSW, Warszawa 2001.

Romana Kolarzowa, ,Zamawianie” Realnego. Konstruowanie tożsamości fantazmatycznej „,narodu politycznego”, „Teksty Drugie” 2015, nr 1, s. 84-95. 
Ewa Kraskowska, Ojcowska żałoba Karola Irzykowskiego, „Teksty Drugie" 2008, nr 5, s. 127-137.

Philippe Lejeune, „Drogi zeszycie...”, „Drogi ekranie...”O dziennikach osobistych, tłum. M. i P. Rodakowie, wyb., wstęp i oprac. P. Rodak, Wydawnictwa Uniwersytetu Warszawskiego, Warszawa 2010.

Philippe Lejeune, Wariacje na temat pewnego paktu. O autobiografii, thum. W. Grajewski i in., Towarzystwo Autorów i Wydawców Prac Naukowych Universitas, Kraków 2001.

Alfonso Mario di Nola, Triumf śmierci. Antropologia żałoby, red. M. Woźniak, tłum. J. Kornecka, Towarzystwo Autorów i Wydawców Prac Naukowych Universitas, Kraków 2006.

Małgorzata Okupnik, Fenomen pamięci. O trudności badań narracji autobiograficznych o utracie, „Acta Universitatis Lodzensis. Folia Sociologica” 2012, t. 41, s. 101-121.

Barbara Olech, Adam Żeromski $w$ listach $i$ wspomnieniach Stefana Żeromskiego, [w:] Żeromski. Tradycja i eksperyment, idea i układ J. Lawski, red. A. Janicka, A. Kowalczykowa, G. Kowalski, Książnica Podlaska im. Łukasza Górnickiego w Białymstoku, Białystok-Rapperswil 2013.

Mieczysław Porębski, Polskość jako sytuacja, „Znak” 2012, nr 690; http://www.miesiecznik.znak.com.pl/6902012mieczyslaw-porebskipolskosc-jako-sytuacja/ [data dostępu: 11.11.2015].

Paweł Rodak, Między zapisem a literatura. Dziennik polskiego pisarza w XX wieku (Żeromski, Natkowska, Dabrowska, Gombrowicz, HerlingGrudziński), Wydawnictwa Uniwersytetu Warszawskiego, Warszawa 2011.

Barbara H. Rosenwein, Obawy o emocje w historii, tłum. J. Wysmułek, „Teksty Drugie” 2015, nr 1, s. 359-391.

Magdalena Saganiak, Świat Żeromskiego czyli Polska. Początek drogiPolska w „Dziennikach” (1882-1891), [w:] Światy Stefana Żeromskiego. Studia, red. M.J. Olszewska, G.P. Bąbiak, Wydział Polonistyki Uniwersytetu Warszawskiego, Warszawa 2005. 
Magdalena Saganiak, „,Wisła” Stefana Żeromskiego - misterium przyrody i historii, [w:] Czytanie modernizmu. Studia, red. M.J. Olszewska, G.P. Bąbiaka, Wydział Polonistyki Uniwersytetu Warszawskiego, Warszawa 2004.

Jan Sowa, Fantomowe ciało króla. Peryferyjne zmagania z nowoczesna forma, Towarzystwo Autorów i Wydawców Prac Naukowych Universitas, Kraków 2011.

Krzysztof Stępnik, Wojenna szarada. Twórczość Żeromskiego w latach 1914-1918, [w:] idem, Rekonesans. Studia z literatury i publicystyki okresu I wojny światowej, Wydawnictwo Uniwersytetu Marii Curie-Skłodowskiej w Lublinie, Lublin 1997.

Jadwiga Zacharska, Między fikcja a dokumentem. „, O Adamie Żeromskim wspomnienie”, [w:] Światy Stefana Żeromskiego. Studia, pod red. M.J. Olszewska, G.P. Bąbiak, Wydział Polonistyki Uniwersytetu Warszawskiego, Warszawa 2005.

Anna Zdanowicz, Źródta i formy polskości. Uroda życia Stefana Żeromskiego, [w:] Czytanie modernizmu. Studia, red. M.J. Olszewska, G.P. Bąbiaka, Wydział Polonistyki Uniwersytetu Warszawskiego, Warszawa 2004.

Stefan Żeromski, Listy 1913-1918, oprac. Z.J. Adamczyk, Spółdzielnia Wydawnicza „Czytelnik”, Warszawa 2008.

Stefan Żeromski, Pisma raperswilskie. Wspomnienia i sylwetki, oprac. Z.J. Adamczyk, Uniwersytet Jana Kazimierza w Kielcach i IBL PAN, Warszawa 2015. 


\section{About Stefan Żeromski's 'Little Pole' and Karol Irzykowski's 'Real Poland' - Private Dimension of Polishness in the Face of the Great War} The article summarizes and compares the two biographical texts by writers who are difficult to compare in terms of aesthetics and political-ideological dimension - fragments of journals by Karol Irzykowski devoted to illness, death and remembrance of his daughter Basia and biographical memory of the dead of tuberculosis son Adam by Stefan Żeromski. The comparative perspective of both narratives of loss is present in their reflection on Polishness, increased in the circumstances of World War I.

The analysis and interpretation shows that bearing witness to such a difficult personal existential experience paradoxically involves the necessity of re-positioning in and to Polishness. The memory of Adam Żeromski is subordinated to the social perspective, frame of collective memory, which makes it understandable why in Żeromski's story he is the 'little Pole', and Basia is the subject to psychological and individual memory, collected memory, so she can be called the great Poland. In this sense, both texts are the media of culture of remembrance, which inherently clarifies and determines the experience of the Great War that seems to confirm the researchers' diagnosis of a breakthrough significance of the period 1914-1918, also in the perspective of Polish identity.

Keywords: narrative of loss, memory, collective memory, collected memory, World War I, the literature of World War I, Polishness. 


\section{Nowości Wydawnictwa UKSW}

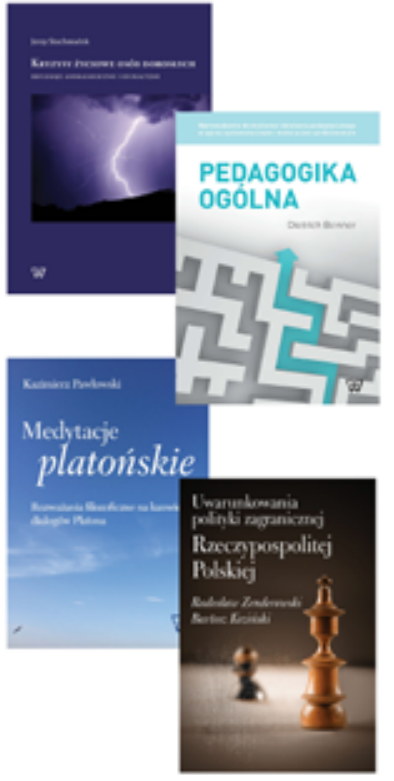

- Jerzy Stochmiałek, Kryzysy życiowe osób dorosłych

- Dietrich Benner, Pedagogika ogólna

- Kazimierz Pawłowski, Medytacje platońskie. Rozważania filozoficzne na kanwie dialogów Platona

- Bartosz Koziński, Radosław Zenderowski, Uwarunkowania polityki zagranicznej Rzeczypospolitej Polskiej

Więcej informacji na stronie: www.wydawnictwo.uksw.edu.pl 